\title{
Economic and Psychosocial Impact of COVID-19 Pandemic on Badhai Hijras: A Qualitative Study
}

\author{
Preeti $^{1} \&$ Shyamkiran Kaur ${ }^{2}$ \\ ${ }^{1}$ Dr. B.R. Ambedkar National Institute of Technology, Jalandhar, Punjab, India, email- \\ preeti.hm.19@nitj.ac.in, https://orcid.org/oooo-ooo3-2279-6532 \\ ${ }^{2}$ Dr. B.R. Ambedkar National Institute of Technology, Jalandhar, Punjab, India, email- \\ kaursk@nitj.ac.in, https://orcid.org/oooo-0oo2-8182-361X
}

\begin{abstract}
Human history has witnessed various natural upheavals, pandemics being one of them. These pandemics whether The Black Death, The Great Plague of London, Russian Flu, Spanish Flu, Asian Flu, HIV/AIDS, SARS, etc. struck down every sphere of human civilization. The devastating economic and psychosocial impact of COVID-19 has been experienced by every group of population whether privileged or marginalised. Hijras (a term used by Serena Nanda for the transgenders in Indian Subcontinent) especially badhai hijras (transgender performers) who are already living on the edges of society have been targeted worst by this pandemic as their livelihood is solely dependent upon their performances on various social gatherings that decreased significantly during the period. These people amidst poor finances are confronting more discrimination by the heteronormative set-up which results in their low physical, mental, and social wellbeing. The objective of the present paper is to study the economic and psychosocial impact of COVID-19 pandemic on hijras in general and badhai hijras in particular. The arguments are supported by various vis-avis interactions with hijras and an NGO working for their well-being in the district Jalandhar, Punjab (India). While using the interview technique, a structural questionnaire for a sample population of badhai hijras was used to collect data for the study. The findings of the research work highlighted the urgent need of providing financial assistance to the badhai hijras. The research work would assist the decision making agencies of government to frame policies for these marginalized individuals which will directly support them in the pandemic.
\end{abstract}

[Keywords- LGBTQ, hijras, badhai hijras, pandemic, COVID-19, Transphobia, Heteronormative]

\section{Introduction}

Pandemics are the adverse form of epidemics faced by human beings that spread over multiple countries, destroy human lives massively, and affect the socio-historical fabric of societies. Pandemic, in simple terms can be defined as a situation when an epidemic crosses the borders and spreads all over the world. In human history, the pandemics like The Black Death, The Great Plague of London, Russian Flu, Spanish Flu, Asian Flu, HIV/AIDS, SARS, etc. are responsible for taking away the major chunk of the population and creating various social and political phenomenon which can further be linked to the individual's psychosocial environment. Besides a life-threatening phenomenon, pandemics leave several other ill effects on a society i.e. shrinking of the world economy and worldwide economic depression.

(c) AesthetixMS 2020. This Open Access article is published under a Creative Commons Attribution Non-Commercial 4.o International License (http://creativecommons.org/licenses/by-nc/4.o/), which permits non-commercial re-use, distribution, and reproduction in any medium, provided the original work is properly cited. For citation use the DOI. For commercial re-use, please contact editor@rupkatha.com. 


\section{COVID-19 Pandemic}

The COVID-19, an infectious disease caused by a newly discovered Coronavirus has adversely affected the lives of every individual across the globe. According to the World Health Organisation (WHO), the COVID-19 infected people will experience mild to moderate respiratory problems but recover without requiring special treatment. (WHO,2020). The most common symptoms of COVID-19 include fever, dry cough, tiredness and aches, soar throat. Diarrhea, Conjunctivitis, headache, loss of taste or smell, a rash on skin or discoloration of fingers or toes etc. are the less common symptoms. (WHO,2020). Older population with underlying medical problems like cardiovascular disease, diabetes, chronic respiratory disease, and cancer are more likely to develop serious illness. (WHO,2020). The WHO COVID-19 Dashboard shows approximately 2.1 million confirmed cases and 7.6 lacs casualties (as on August 16, 2020).

\section{Marginalised Sexualities and Role of Discourse}

The economic and psychosocial impact of COVID-19 has been witnessed by every group of population whether privileged or marginalised. However, the marginalised communities and sexualities in India have been the worst sufferer of the pandemic. The term marginalised is itself an outcome of the political interest of a particular or hegemonic group in any strata. This process of pushing certain fragments to the margins is carefully programmed by certain hegemonic discourses. Inspired by the contribution of Foucault in understanding the structure of any society, the gender theorists like Judith Butler criticised the construction of sexuality in the discourses of medicine, law and religion and tried to explore the sexuality based oppression along with other oppressive forces- patriarchy and racism. They focussed upon the formation of permissible(heterosexuality) and impermissible(homosexuality) behaviour as a result of the discourses generated by the heteronormative society. (Nayar, 2009:187) Thus, in every society, there is the co-existence of concepts i.e 'pure' or 'complete' for heterosexuals and 'deviant' and 'other' etc for the LGBTQ community or the third gender in general. (Nayar, 2009:188)

Foucault in his essay The Order of Discourse states,

"There exists in our society another principle of exclusion, not another prohibition but a division and a rejection. I refer to the opposite between reason and madness." (Foucault, 1970:53).

Queer sexualities being categorised as mental disorders by forming certain medical discourses (the American Psychiatric Association being one of them) are hence living on the margins of any social setting. There remains a hegemonic power that regulates the discourses related to the sexuality of unrecognised entities in a system. The 'heterosexuals' possess the authority to categorise all other individuals with different 'brain sex' as non-humans or queer people (queer because they are unable to understand their gender). They are often mystified. This can be compared to the concept of mystification of the female gender as propounded by Simone de Beauvoir in her essay 'Myth and Reality'. She states that a man or any other regulating authority mystifies another entity whom he/it is unable to understand. This is apparent in the case of trans people as well where the heteronormative society fails to accept the existence of different brain sex inside a trans person and hence mystifies his/her personality. So, transgenderism and cross-dressing are rendered as mental disorders. 


\section{Defining Hijras}

'Hijra' is a popular term used for transgenders in India. Serena Nanda, an American author, anthropologist, and professor emeritus defines hijras as,

"neither men nor women, function as an institutionalized third gender role. Their ambiguous sexual nature, through which they embody the power of generativity of the goddess, accounts for their traditional occupation, that of performing after the birth of a child, at weddings, and at temple festivals." (Nanda,1999:viii)

However, the mystical term hijra (mystical because the common folk is not able to comprehend the actual account of it) encompasses various other definitions despite their role as cultural performers. One definition is restricted to the autonomy that a person who is biological male but has feelings or brain sex of a female is a hijra. Another definition is related to the individuals who are "born that way" or are intersexed means they are born with different genitalia and biologically neither man nor woman but they experience the gender identity quite similar to a woman. Hijras in India do various odd jobs/activities to sustain their livelihood. These activities include their performance at weddings, temples and other social gatherings, mahanti (sainthood) begging at public places, sex work, etc. The hijras who sustain their livelihood by performing are badhai hijras.

\section{History and Criminalisation of Sexual Minorities}

India, though having a vivid historical, mythological, and scriptural background yet exhibits monolithic thinking towards sexuality. The idea of having a restricted outlook for the hijra community lies in the description of four ashrams in the scriptures. These four ashrams(stages) can also be called as the duties of an individual in a particular age group. In these ashrams, prime importance is given to man and woman and hence the formation of a family is considered as the utterly significant task in the life of an individual. So people of the trans community are not assigned any recognition as beings because they fail to create a family.

In the Mughal period, hijras were kept in 'harem' (that part of palace where men are not allowed to enter) as guardians of royal women who were not allowed to be seen by any 'other' man. They were popularly known as 'khwajsarais'. Though they enjoyed the legal status of being slaves yet they were politically significant courtiers, government officials, military commanders, etc. The basis of this political trust by the royal court was the incapability to produce children as a result they could not attempt to consolidate power for their lineages. (Newport,2018)

While with the conquest of Britishers their position suffered a setback as the colonial masters have the least tolerance for the people having these kinds of tendencies. With power in their hands, they criminalised all such tendencies of being cross-dressing, transgenders, being drag queens, etc. that fall outside the binaries of man and woman. In 1861, the British government criminalised homosexuality and other 'unnatural offences'. However, in September,2018 the Supreme Court of India decriminalised the section 377 of the Indian Penal Code which stated,

"Whoever voluntarily has carnal intercourse against the order of nature with any man, woman or animal shall be punished with imprisonment for life, or with imprisonment of either description for a term which may extend to ten years or with a death penalty, and shall also be liable to fine". 


\section{COVID-19 and badhai hijras}

With the advent of COVID-19 and the rise in its cases the government of India implemented lockdown all over the country. Looking at the threatening leap in COVID-19 cases in Punjab, the state government appealed the common folk not to visit crowded places and gatherings. Several decisions were taken and the total numbers of marriage gatherings were restricted to 30 . At the same time, the gatherings at all cultural and religious melas (religious and cultural gatherings) were also restricted to a certain limit. Hence, during this time the badhai hijra community suffered a great financial loss as the common people either postponed the wedding dates or the badhai hijras were not entertained at such occasions. The community could not go outside for collecting badhai (money collected from dance performances) from the families where a male child was born.

\section{Methodology}

To represent the economic and psychosocial impact of COVID-19 on badhai hijras a survey was conducted in the district of Jalandhar in Punjab, India. Shaan Foundation, an NGO working for the welfare of the LGBTQ community assisted in the collection of data through questionnaire and interview method. The foundation was established in 2011 under the supervision of Deepak Rana (Chahat), a well-qualified transwoman and LGBTQ rights activist, has its offices also in other districts of Punjab namely Ludhiana and Mansa. The prime motive of the organisation is to disperse HIV/AIDS and gender awareness among the members of the LGBTQ community. It also holds an LGBTQ clinic where HIV, HCV, and full-body check-ups are conducted free of cost for the members of the community. In this clinic, an anti-HIV medication PReP(Pre-Exposure Prophylaxis) is also being provided to the members which reduces the risk of getting HIV infection from an HIV positive person. The organisation has been a part of the project Pehchan, funded by Global Fund. To promote 'outing' among LGBTQ people, the organisation is running an Instagram page Aao Gallan Kariye.

According to the organisation, there are 2095 LGBTQ community members in the district Jalandhar out of which around 500 are badhai hijras. A random sample of 20 was collected from the population of badhai hijras in the district. 15 questions aiming to extract the economic and psychosocial impact of COVID-19 on badhai hijras were formed. The questionnaire distributed among the sample population was translated into Punjabi as most of the individuals cannot understand English. However, the English version of the questionnaire has been mentioned in section appendix. Question no. 14 and 15 were formed to invite suggestions from the community that will help the policy-making agencies of the government to take appropriate steps for the community during COVID-19 and afterward.

\section{Research findings:}

\section{Impact on Income}

Almost all the badhai hijras in the sample population believe that their income during COVID-19 has reduced to a considerable level resulting in their low standard of living. 15 out of 20 members are living with their biological family while 5 out of 20 with the community members. It is worth noting here that those who are living with their family are the sole bread earners (as their parents are too old or either of the parents is dead) and are not getting any kind of financial help from the family. 


\section{Begging}

Since COVID-19 pandemic has severely crippled the world economy affecting many individuals' lives and compelling them to look for another ways of earning a livelihood. The pandemic has created a worse impact on the occupation of badhai hijras too. Due to sudden fall in the number of social and religious gatherings, some of the badhai hijras have now started begging at traffic signals and shops which they consider more insulting than before. While conducting interviews some of the badhai hijras informed their utterly poor economic level on account of COVID-19 as they were not able to pay the loans and EMIs.

\section{HIV Risk Due to Sex Work}

The hijra community in India is also indulged in sex work but the badhai hijras prefer to earn money through their performances. The survey highlighted that due to the failure in getting adequate sum as badhai, 8 out of 20 badhai hijras (between the age group of 17 to 40) have now been indulged in sex work, an illegal act, to sustain their livelihood. Hence, the risk of HIV/AIDS among them has increased than ever. During an interview, a badhai hijra expressed that she is getting mere Rs 300-500 for sex work and even out of this meagre amount the Punjab Police personnel extract a big chunk to what they call 'hafta' (settled amount of money taken as bribe after a particular period of time). So, it would be appropriate to state that even the law-keepers are not lagging behind to exploit this marginalised community.

\section{No Relief Package for the Community}

Although the Indian government has tried its best to provide relief packages to the needy people in this grim period of pandemic, but, the survey based facts highlight the government's failure in providing relief packages or ration kits to the badhai hijras. This could be due to a lack in proper documentation about the community. The community members in these hard times are either helping each other or an NGO provided a ration kit to them.

\section{Selling and Mortgaging of Household Items}

As the badhai hijras are facing economic crises during COVID-19, they have to sell off their valuable households items to maintain their expenses. Meera,(name has been changed to conceal the identity of the person) a 35 year old illiterate badhai hijra has to sell her ornaments to pay the EMIs of various household items. She also added that due to COVID-19, there is a severe decrease in the income of common people and some people have lost their jobs too. In this way they are unable to give badhai to hijras.

\section{Psychosocial Impact of Low Income and Public Behaviour}

Economic insecurity along with the prevalent discrimination and disrespect during COVID-19 has added to the worries of the badhai hijra community. The responses of Question no. 12 and 13 in the questionnaire by the sample population are quite similar in nature. Almost all the badhai hijras are disrespected in the heteronormative society. They often receive derogatory remarks like mamu, chhakka, tempo, khusra, taxi, khoja, etc. from society. They face insulting remarks, social rejection, public hated and anger throughout their life and hence become the victims of transphobia. During COVID-19 the atrocities upon these sexual minorities have increased than before. From the responses in the questionnaire, all the members of the community stated that they are living as neglected beings in a system. Nisha, writes, "loka da vitkara sahi nahi hai."(the behaviour of people towards us is not just). Another badhai hijra, Seema, said, "loki sade te hasde $a a$, taanhe marde aa" (people laugh at us and address us in a taunting way). Reema explained the attitude of people during COVID-19 as, "Lok COVID-19 dauran dare hoye han. Badhai len gye 
samay sanu gharan cho dhakke vi maar dinde han." (people are scared of COVID-19. They turn us out of their houses forcefully whenever we ask for badhai).

This continuous discrimination and rejection before and during COVID-19 adversely impact the mental health of individuals resulting in the untoward decisions taken by them. (Real names have been changed to conceal the identity of individuals).

\section{Discussion}

From the above findings, it is evident that the community urgently needs the attention of policymakers especially, during the pandemic. Although the government has assisted other weaker sections of the society by providing them grocery, free cooking gas, monetary assistance, etc. yet it fails to assist the hijra community. The following efforts are needed on part of the government to help this community out from the pandemic.

\section{To Develop a Welfare Board for Proper Documentation and Providing Relief Packages}

The community is expecting the state government to develop a welfare board so that the exact number of their population must be known and their needs may be considered during the crises. There is an urgent need to have proper documentation of these sexual minorities. Hence, it can also be stated that the inability of the state government in distributing the relief packages lies perhaps in the absence of proper data, documentation, registration, etc. of the community which is further subject to gender politics.

\section{Employment and Unemployment Allowance}

While conducting interviews of the badhai hijras I witnessed a zeal of having skill-based jobs among them. Most of them expressed their interest in dancing, cooking, driving, stitching, doing make-up, modeling, etc. About 80 percent of the sample population(below intermediate qualification) showed their interest in doing skill-based jobs as they don't want to go for badhai, begging, and sex work. They want to get indulged in respectable jobs as the other people do. Hence government must also introduce and install skill based training programs and institutions for the trans community. Here, private sectors are also expected to reserve certain positions for hijras. So far as the present economic crises are concerned they must be granted unemployment allowance.

\section{Special Pension Schemes}

Pension schemes are meant to provide economic security to an individual in his or her old age. The badhai hijras, as their occupation is to earn money through their performances are unable to perform in old age. So a special pension scheme should be started for them to provide them economic security. In India, the Odisha state government started a pension scheme "Madhubabu Pension Yojana" (MBPY) in which around 5000 transgenders will get benefit of Rs. 500, 700 and 900 per month depending on their age categories. (The Indian Express, 2020)). Andhra Pradesh and Kerala governments had earlier announced pension schemes for them.

\section{Education}

The data collected from the sample of the survey highlighted 40 percent of the badhai hijras have educational qualifications less than intermediate as a result they are unaware of the policies of the government. Most of the hijras were not able to write answer in their regional language but some hijras showed their interest in acquiring education. Nancy, a badhai hijra, wants to pursue B.sc in 
Non-Medical stream but due to the discrimination prevalent in the society, she is unable to go to college. So the provision of giving education through evening schools should be considered by the state government. For higher education the Akhil Bhartiya Kinnar Shiksha Seva Trust (All India Transgender Education Service Trust) has already laid the foundation stone of India's first Transgender University in the district Khushinagar, Uttar Pradesh.

\section{Start-ups Programs Solely for Hijra Community}

The present era belongs to advancements and innovations and the Indian government is also encouraging budding entrepreneurs. There are various areas where the hijras can prove themselves as entrepreneurs. To encourage and empower them special start-up programs and funds should be allocated to the community.

\section{Conclusion}

The field research brought forward many startling revelations as I got to know the real-life conditions of badhai hijras. The community, though often referred to as sexual minority carries a vast sub-culture having roots in mythology and human history. In Punjab, they are often regarded as Mahantji or babaji(holy person). However, the ambivalent behaviour of the common people towards the hijras can also be observed in Punjab. Like the people of other states don't consider it a good omen if a hijra/ badhai hijra talks or comes near to an expecting mother. During the interviews with badhai hijras, some hijras (who are in contact with their families) were not allowed to see and talk to their expecting siblings. Even after the birth of the child, they were not allowed to see the child for months which further exposes the dual standards and hypocrite nature of common people. People want their children to be blessed by the avatars of God but they don't want to have a hijra in their family. Another attitude of society is seen when they mistreat these "holy" beings and offer a minimal sum for sex work.

While conversating with the founder of SHAAN Foundation, it was revealed that the hijra community cannot be bound to mere seven gharanas(houses). There are more than seven gharanas in Punjab itself. Sarhandiye, Dhakwayiye, Sujaniye, Monne, Matrane etc are the popular gharanas in Punjab. Hence, in my opinion any transgender/LGBTQ theory in itself is a limited tool, unable to grasp, demonstrate, and represent their actual condition.

Despite of having an established sub-culture, the badhai hijras have been forced to live on the fringes of society by the dominant heteronormative set-up. The gender role of performing at various occasions was assigned to them as the dancing of a woman in public gatherings was not considered as a good act for dancing was seen as an expression of sexual desire or instinct. Woman, as subaltern, was not expected to express at all.

The condition of badhai hijras during the pandemic has raised many questions against the government and the common masses. Being neglected and mistreated for not falling into the category of 'normal' they have the least expectations from the society and also from the government to some extent. Hence, they are more interested in vocational training and skillbased occupations so that they may not suffer the economic crises that they are facing now on account of COVID-19. The analysis of the situation of badhai hijras' during COVID-19 through this research paper would help in forming policies and sensitize the common people. 


\section{References}

Ahmed, S. (2016). Interview with Judith Butler. Sexualities, 19(4), 482-492.

Abrams, M. H., \& Harpham, G. (2011). A glossary of literary terms. Cengage Learning.

Beauvoir, S. D. (2001). From The Second Sex Chapter XI Myth and Reality.

Bhardwaj, V., \& Chatterji, S. (2017). The Plight of The Third Gender: Quest for Identity in the Narratives Me Hijra Me Laxmi and The Truth About Me: A Hijra Life Story (Doctoral dissertation, Lovely Professional University).

Butler, J. (2004). Undoing Gender. Psychology Press.

Callis, A. S. (2009). Playing with Butler and Foucault: Bisexuality and Queer theory. Journal of Bisexuality, 9(3-4), 213-233.

Das, R. (2015). Representation and Categorization: Understanding the hijra and transgender identities through personal narratives. Rupathka Journal on Interdisciplinary Studies in Humanities, 7, 196205 .

Foucault, M. (1970). The Order of Discourse. Inaugural lecture at the Collège de France. Language and Polifics, Basil Blackwell, Oxford.

LGBT Glossary(n.d) Retrieved from http://web.jhu.edu/LGBTQ/glossary.html

Nanda, S. (1999). Neither man nor woman: The hijras of India. Cengage Learning.

Nagoshi, J. L., \& Brzuzy, S. I. (2010). Transgender theory: Embodying research and practice. Affilia, 25(4), 431-443.

Nayar, P. K. (2009). Contemporary literary and cultural theory: From structuralism to ecocriticism. Pearson Education India.

Newport, S. E. (2018). Writing Otherness: Uses of History and Mythology in Constructing Literary Representations of India's Hijras. The University of Manchester (United Kingdom).

PTI. (2020. July 4). Odisha government to give monthly pension to transgenders. The indian express, P1. Retrieved from http:// https://www.newindianexpress.com/

Stryker, S. (2017). Transgender history: The roots of today's revolution. Seal Press.

Appendix- Questionnaire
Economic and Psychosocial Impact of COVID-19 Pandemic on Badhai Hijras: A Qualitative Study
QUESTIONNAIRE
\begin{tabular}{|l|c|}
\hline NAME & \\
\hline AGE & \\
\hline ADDRESS & \\
\hline CONTACT NUMBER & \\
\hline
\end{tabular}

1. What is your qualification?

2. What is your occupation/ part time job?

3. Do you live in a rented accomodation or you have a house of your own? 
9 PTI. (2020. July 4). Odisha government to give monthly pension to transgenders. The indian express, P1. Retrieved from http:// https://www.newindianexpress.com/

4. Do you live with your biological family or with your community members?

5. Do you get any kind of financial assistance from your biological family?

6. Do you believe COVID-19 has adversely affected your profession as a Badhai hijra?

7. What was your approx monthly income before and during COVID-19?

8. How are you managing your finances during COVID-19?

9. Are you being provided finacial assistance under some government policy or Non-government organisation? If yes, specify.

10. Are you getting grocery items and other facilities under some government policy or Nongovernment organisation? If yes, specify.

11. Are you aware of the policies of the government regarding your community?

12. What is the attitude of common people for the Badhai hijras during COVID-19?

13. What are the problems that have you been facing regarding your gender since childhood?

14. What policies and measures that government should take to improve your status?

15. What changes do you want in the attitude of common people towards you and your community?

Preeti is a Research Scholar in the Department of Humanities and Management, Dr. B.R. Ambedkar National Institute of Technology, Jalandhar, Punjab, India

Dr. Shyamkiran Kaur is an Assistant Professor in the Department of Humanities and Management, Dr. B.R. Ambedkar National Institute of Technology, Jalandhar, Punjab, India 